\title{
MENGENAL
}

\section{FENOMENOLOGI PERSEPSI MERLEAU-PONTY TENTANG PENGALAMAN RASA}

\author{
Tanius Sebastian $^{1}$
}

\author{
| Graduate Student \\ STF Drijarkara \\ Jakarta, Indonesia
}

\begin{abstract}
:
Phenomenology of Perception is one of the main philosophical works of a France phenomenological philosopher, Maurice Merleau-Ponty. In this book, Merleau-Ponty elaborates his reflection on the nature of the body based on the perception of the world. In "Sense Experience," which is part of Phenomenology of Perception, explains the bodily experience and its relation to human's mode of being in the world. This part is important to look upon, for it serves as the basis for Merleau-Ponty's phenomenological thought on perception. In "Sense Experience", while affirming his critique on empiricism and intellectualism, Merleau-Ponty also reflects the meaning of sense experience, the unity of the sense, the analytical attitude, the nature of the body, and the ambiguity of sense experience itself. Two key ideas surface from "Sense Experience," that is, sense experience with and through the body, and bodily experience with and through the world. One might speak of the world, yet one is part of it. It is the body that allows such ambiguity.
\end{abstract}

Keywords:

sense experience $\bullet$ subject $\bullet$ body $\bullet$ empiricism $\bullet$ intellectualism $\bullet$ sensation $\bullet$ perception 


\section{Introduksi}

Phenonemonology of Perception (PP) dari Maurice Merleau-Ponty (19081961) adalah salah satu dari karya-karya utama fenomenolog asal Prancis tersebut. ${ }^{2}$ Pada tulisan ini saya akan menelaah salah satu bab, "Sense Experience," bagian dari buku tersebut. Di dalam teks ini, Merleau-Ponty menjabarkan lebih lanjut gagasan tentang tubuh sebagai titik tolak cara mengada manusia dalam dunia. Keterarahan seluruh hidup dan diri, termasuk tubuh fisik, menunjukkan adanya "rasa" (sense) terhadap dunia. ${ }^{3}$ Merleau-Ponty merefleksikan secara mendalam perihal rasa ini di dalam bab ini. Pembacaan terhadap bab ini menantang untuk memahami rasa dan pengalaman tentangnya. Merleau-Ponty mengungkapkan argumentasi filosofis yang menjadi landasan bagi refleksi pengalaman bertubuh. Dengan kata lain, pengalaman rasa di sini adalah titik tolak untuk mengerti bagaimana memersepsikan hubungan antara tubuh dengan dunia secara fenomenologis.

Bab tersebut terdapat di bagian kedua PP. Di bagian pertama, MerleauPonty mengupas perihal hakikat tubuh. Yang dibicarakan di bagian kedua adalah dunia sebagaimana dialami dan dirasakan oleh tubuh. Pada bagian pertama buku PP, Merleau-Ponty berpendapat bahwa tubuh bukan sekadar objek dalam dunia. Dikatakannya, "Tubuh adalah jangkar kita dalam dunia". "Tubuh merupakan sarana bagi berlangsungnya pengalaman perseptual. Marshall menjelaskan hakikat tubuh tersebut seperti sebuah "pangkal dinamis pengalaman perseptual". 5 Artinya, tubuh adalah dasaratau asal bagi berlangsungnya eksistensi manusia dalam dunia. Kata 'dinamis' menunjukkan bahwa dasar atau asal tersebut bukan merupakan kausalitas, melainkan eksistensi bertubuh yang senantiasa berjalinan dengan dunia. Manusia dibentuk sekaligus membentuk dunia, mempengaruhi namun kerap dipengaruhi pula oleh dunia, serta memaknai bahkan dimaknai oleh dunia.

Bagian kedua PP membahas hakikat dunia tersebut, yakni dunia yang memiliki interaksi mendasar dengan tubuh manusia. Di dalam semacam teks pembukaan untuk bagian kedua, Merleau-Ponty menggambarkan keterhubungan tubuh dengan dunia seperti jantung (heart) dari organisme. Tubuh berada di dalam dunia. Seperti jantung yang menjadi pusat serta 
bagian terpenting dari hidup organisme, tubuh pulalah yang menjadikan dunia itu hidup, bergerak, dan membentuk sebuah sistem. ${ }^{6}$ MerleauPonty ingin menekankan bahwa keberadaan dunia beserta objek-objek di hadapan manusia itu bukan hasil rekonstruksi pikiran atau ide-ide belaka. Dunia beserta objek-objek tersebut dialami sebagai sesuatu yang sangat terkait dengan kesatuan tubuh. ${ }^{7}$ Oleh karena itu, keterhubungan tubuh dengan dunia lebih merupakan korespondensi melalui apa yang dihidupi, daripada sistem dan korelasi yang objektif. ${ }^{8}$

Merleau-Ponty berpendapat bahwa persepsi atas objek yang berada di luar atau terpisah dari tubuh kita pada dasarnya dikenai (affected) oleh persepsi atas tubuh kita sendiri. Setiap persepsi dari objek-objek eksternal bersinergi dengan persepsi tubuh. "Setiap persepsi eksternal langsung bersinonim dengan persepsi tertentu atas tubuhku, sebagaimana juga setiap persepsi atas tubuhku dibuat eksplisit dalam bahasa persepsi eksternal". ' Dengan begitu, manusia tidak lagi berpikir menurut pola pembedaan subjek-objek karena "telah menemukan di balik pengetahuan yang objektif dan lepas atas tubuh, bahwa terdapat pengetahuan lain yang senantiasa ada pada kita dan fakta bahwa kita adalah tubuh kita". ${ }^{10}$

Untuk itu, Merleau-Ponty berpendapat bahwa yang mesti dipahami adalah kontak antara tubuh dan dunia. Locus dari kontak tersebut adalah pengalaman manusia dalam dunia melalui dan bersama tubuhnya. Fenomenologi Merleau-Ponty mengungkapkan bahwa pengalaman alamiah manusia di dalam dunia berwujud persepsi. ${ }^{11}$ Bagaimana menghidupi pengalaman mendasar itu melalui dan bersama tubuh, khususnya saat 'merasakan' dunia? Pertanyaan inilah yang menjadi titik tolak MerleauPonty dalam menggugah pemaknaan atas pengalaman rasa.

Ada suatu jenis kegiatan yang bisa dipakai mengilustrasikan refleksi Merleau-Ponty tentang pengalaman rasa di dalam tulisannya. Kegiatan itu adalah memasak yang dikompetisikan. Orang bisa menemukan beragam bentuk acara seperti ini di televisi. Kalau menyimak kegiatan tersebut, para juru masak yang bertanding bukan sekadar mengolah bahan masakan dalam kadar atau ukuran tertentu. Seringkali mereka melakukan improvisasi terhadap resep yang ada. Sering terdengar pula ungkapan bahwa yang dibutuhkan dalam memasak adalah feeling atau ketepatan rasa dan waktu yang tidak bisa diuraikan dalam penjelasan akurat. Juru masak kerap mengandalkan kepekaan lidah, penciuman aroma masakan, dan 
pengiraan takaran bumbu. Aspek pengalaman akan turut menentukan, misalnya, lama pengalaman memasak juru masak.

Ilustrasi di atas memperlihatkan bahwa rasa merupakan salah satu wujud persepsi. Hasil masakan dari olahan bahan dan dengan penampilan tertentu menghasilkan persepsi yang tertentu pula. Dengan kata lain, terdapat kualitas rasa tertentu. Penilaian terhadap 'rasa' menunjukkan adanya makna kualitas rasa itu. Tampaknya penilaian rasa menunjukkan suatu relativisme atau subjektivisme tentang rasa, namun gagasan Merleau-Ponty tentang pengalaman rasa justru mengemukakan bahwa hakikat sebuah objek sesungguhnya mengandalkan keterlibatan tubuh dengannya. Dalam teks tersebut, Merleau-Ponty menggambarkan bagaimana keterlibatan tubuh dalam dunia bersifat ambigu. Pengalaman rasa itu bukan soal penerapan kategori kausalitas seperti menurut kaum empirisis. ${ }^{12}$ Pengalaman rasa bukan pula soal penentuan elemen pengalaman yang ini atau itu berdasarkan akal budi, seperti kata kaum intelektualis. ${ }^{13}$ Dengan memandang rasa sebagai persepsi, Merleau-Ponty melanjutkan analisisnya tentang sensasi. Teks ini mengkritik dua pandangan yang kerap menyalahartikan persepsi sebagai sensasi, yakni empirisisme dan intelektualisme. Empirisisme memahami rasa sebagai sejumlah unit sensasi yang berdiri sendiri di luar subjek, yang kualitasnya terpisah-pisah, dan tak memiliki kesatuan rasa. Intelektualisme memahami rasa sebagai makna yang pasti dan dapat ditentukan menurut kesadaran subjek.

\section{Pokok-Pokok Pembahasan}

Dalam teks ini, Merleau-Ponty membahas perihal sensasi, namun kali ini dalam interaksinya dengan pengalaman rasa melalui dan bersama tubuh. Di sini, tubuh dipahami sebagai subjek persepsi, yakni diri manusia yang berhubungan dengan dunia. Pengertian subjek persepsi bisa dirujuk pada rumusan Merleau-Ponty sendiri: "Kita yang berada di dalam dunia melalui tubuh kita", serta "Kita yang memahami dunia dengan tubuh kita." ${ }^{14}$ Ia mengajukan keberatan terhadap dua pandangan yang mereduksi pengalaman tubuh yang merupakan subjek persepsi, yaitu empirisisme dan intelektualisme. Dalam pandangan Merleau-Ponty, keduanya tampil sebagai pikiran objektif. "Pikiran objekif tidak menyadari subjek persepsi."'15 Berdasarkan pikiran objektif, pengertian subjek persepsi mesti jatuh hanya pada salah satu dari antara dua bentuk alternatif berikut: sensasi sebagai 
suatu kesadaran atau sensasi sebagai kesadaran akan sesuatu; eksistensi berkesadaran (being-for-itself) atau eksistensi nir-kesadaran (being-in-itself); alam yang dibentuk (natura naturata) atau alam yang membentuk (natura naturans). ${ }^{16}$

\section{Keberatan terbadap Empirisisme dan Intelektualisme}

Keberatan Merleau-Ponty tampak dari uraiannya tentang tendensi reduktif empirisisme dan intelektualisme. Empirisisme tidak mengacuhkan subjek persepsi karena yang dilihat adalah adanya subjek tertentu, dengan tindakan tertentu, dan bagaimana menggambarkan aktivitas tersebut. Empirisisme mendeskripsikan sejumlah sensasi yang berasal dari seorang subjek; subjek yang menyadari merupakan tempat di mana berbagai sensasi itu berlangsung dan berkaitan. Ia mengajukan keberatan terhadap gagasan ini dengan argumentasi bahwa dari luar (outside), persepsi memang tampak seperti yang dideskripsikan tersebut. Akan tetapi, ia berpendapat bahwa dari dalam (inside), persepsi tidak berkenaan dengan rangsangan (stimuli) secara fisis dan organ atau indera perasa secara biologis, melainkan merupakan pengalaman yang dihidupi. Ia memandang persepsi bukan sebagai suatu kausalitas, melainkan sebagai "sebuah penciptaan kembali dan pembentukan kembali dunia di setiap saat." ${ }^{17}$ Persepsi bukanlah soal rasa dan tanggapan atas rangsangan biologis tertentu, seolah-olah persepsi dan rangsangan biologis pada tubuh seperti suatu perbandingan satu-satu.

Intelektualisme sebenarnya memiliki inti pandangan yang sama dengan empirisisme. Pada intelektualisme, yang kini berperan mendeskripsikan persepsi adalah Ego transendental. Melalui Ego transendental tersebut, tesis-tesis empirisisme dibalik: dari suatu kesadaran menjadi kesadaran akan sesuatu; dunia menjadi korelasi pikiran tentang dunia. ${ }^{18}$ Sama halnya dengan empirisisme, intelektualisme juga menampilkan dunia yang-sudahjadi, yakni dunia yang dapat digambarkan. Maka dari itu, dunia, tubuh, dan diri empiris dipandang seperti sebuah sistem yang disubordinasikan pada seorang 'pemikir universal'. Merleau-Ponty berpendapat bahwa subjek pemikir tersebut tidak dilibatkan secara aktual karena yang menata sistem pengalaman tersebut adalah pikiran. Dengan begitu, intelektualisme pun memahami pengalaman sebagai hubungan kausal yang terjadi secara abstrak dan luas, atau yang Merleau-Ponty sebut dengan "hubungan kausal yang terpencar dalam konteks peristiwa kosmis." ${ }^{19}$ 
Kritik Merleau-Ponty terhadap empirisisme dan intelektualisme menjurus pada pertanyaan reflektif seputar bagaimana manusia mempersepsi dunia. Merleau-Ponty bertanya, "Bagaimana kita bisa dibingungkan dengan tubuh kita?" Juga, "bagaimana dunia tidak menampilkan dirinya sebagai yang sempurna eksplisit?" "Mengapa dunia itu tampil secara gradual belaka dan 'tidak pernah dalam keseluruhannya'?"20 Ilustrasi pengalaman memasak di atas mungkin bisa membantu menjelaskan pertanyaan-pertanyaan ini. Bayangkan juru masak ditanya oleh seorang juri yang terkesan oleh rasa masakannya, "Bagaimana kamu bisa menghasilkan rasa yang begitu lezat dan pas seperti ini?" Juru masak akan menjawab, "Saya tidak tahu pasti. Saya hanya memperkirakan takaran bumbu dan mencicipi dengan lidah saya." Ketidakpastian, perkiraan, alias ambiguitas pengalaman rasa dalam memasak tidak masuk akal berdasarkan empirisisme dan intelektualisme. Dengan kata lain, empirisisme dan intelektualisme tidak mampu memahami subjek persepsi karena tubuh serta diri empiris menjadi objek dan refleksi ditentukan oleh Ego transendental.

Berdasarkan keberatan dan kritik terhadap pikiran objektif dalam rupa empirisisme dan intelektualisme tersebut, Merleau-Ponty menawarkan pemahaman seksama perihal sensasi. Dari situlah, menurutnya, orang bisa menemukan "hubungan yang hidup dari orang yang mempersepsikan dengan tubuh dan dunianya." 21

\section{Tentang Makna Pengalaman Rasa}

Seperti yang disampaikan oleh Marshall, tesis Merleau-Ponty dalam pembicaraan tentang makna sensasi adalah bahwa makna ditemukan sebagai yang terberi dalam sensasi. ${ }^{22}$ Artinya, sensasi itu bermakna. Namun, Merleau-Ponty berkeyakinan bahwa sensasi bukanlah suatu keadaan tertentu (state) atau suatu kualitas, bukan pula kesadaran akan sesuatu atau akan kualitas tertentu. Untuk mendukung keyakinannya ini, ia merujuk pada gagasan dan eksperimen psikologi induktif. Setiap kualitas yang ada, macam warna dan bunyi, dimasukkan ke dalam sebuah bentuk sikap tertentu. ${ }^{23}$ Merleau-Ponty mencontohkan hal ini dalam gerakan otot yang dipengaruhi oleh perangsangan sensoris. Gerak tubuh tertentu berbeda-beda tergantung pada lapangan visual yang berupa warna tertentu. Ditemukan suatu "warna lapangan visual mengenai akurasi reaksi-reaksi 
subjek". Eksperimen warna-gerakan ini menunjukkan bahwa setiap warna bertindak dengan sikap tertentu sehingga di dalamnya terkandung nilai motorik. Sensasi atas rangsangan lapangan visual itu memiliki maknanya. Ditunjukkan bahwa warna merah dan kuning membantu penggerakan anggota tubuh mendekati poros median atau mendekati badan (aduksi), biru dan hijau membantu gerakan ke arah luar sumbu badan (abduksi). Merleau-Ponty mengungkapkan makna dari gerakan fisik tersebut. Pada aduksi, organisme mengarah pada rangsangan dan ditarik oleh dunia, sedangkan pada abduksi organisme itu berbalik dari rangsangan. ${ }^{24}$ Hal ini menegaskan bahwa sensasi bukanlah kualitas tertentu (quale), tapi tampil sebagai dengan fisiognomi penggerak dan memiliki makna yang hidup.

Merleau-Ponty memperingatkan agar eksperimen warna-gerakan tidak membuat orang jatuh ke dalam cara pandang empirisis dan intelektualis. Empirisisme akan menyatakan bahwa reaksi gerakan merupakan efek dari warna atas tubuh kita, sedangkan intelektualisme akan menganggap fisiognomi penggerak warna ditentukan di dalam kesadaran. MerleauPonty menyatakan bahwa makna dari penggerak warna hanya dapat dipahami hanya bila makna tersebut bukan kualitas yang ditampilkan kepada seorang subjek yang berpikir dan mengobservasi atasnya. Tidak pula makna itu merupakan kesadaran akan gerakan-gerakan yang dibuat. ${ }^{25}$ Bagi Merleau-Ponty, psikologi induktif berhasil menerangkan pengalaman warna. Hijau dipahami sebagai warna yang mengistirahatkan. Penelitian Goldstein terhadap pasien-pasiennya memperlihatkan bahwa merah dianggap berefek mengoyak dan kuning menyengat. ${ }^{26}$ Menurut MerleauPonty, warna memberikan dirinya melalui pengalaman sikap tubuh tertentu yang memang sesuai dengan warna itu. Artinya, warna itu menjelma menjadi makna melalui dan bersama gerak tubuh.

Untuk dapat menangkap makna dari sensasi atas warna, MerleauPonty berargumen, orang harus menghidupi kualitas warna itu dengan tubuhnya. Misalnya, terhadap warna merah yang menandakan kekerasan atau terhadap warna hijau sebagai ketenteraman, orang tidak bertanya tentang 'bagaimana' dan 'mengapa' bisa begitu. Ia mengatakan bahwa "kita harus menemukan kembali bagaimana cara untuk menghidupi warna-warna tersebut sebagaimana yang tubuh kita lakukan, yakni sebagai kedamaian atau kekerasan dalam bentuknya yang konkret". ${ }^{27}$ Di sini, kembali muncul pertanyaan. Apakah hubungan antara perasa dengan 
yang dirasakannya, antara sensasi dengan penerimanya, memang bisa dijelaskan? Apakah pengalaman rasa ini melulu subjektif, bergantung pada situasi masing-masing orang, dan dengan demikian bersifat relatif? Orang mesti menghindari tendensi empirisis dan intelektualis dalam menjawab pertanyaan ini. Merleau-Ponty mengingatkan hal-hal berikut. Pertama, hubungan tersebut jangan dilihat sebagai hubungan antara dua fakta yang berbeda dan terpisah (distinct). Inilah cara pemahaman empirisisme, yakni sensasi sebagai keadaan atau kualitas tertentu (state of consciousness). Kedua, dalam kerangka hubungan itu, subjek sensasi bukanlah seorang pemikir yang menelaah kualitas-kualitas yang ada. Intelektualisme persis memusatkan subjek dengan rasionalitasnya pada hubungan rasa-merasa. Akibatnya, pengalaman rasa dimengerti sebagai pengetahuan atau kesadaran akan rasa (consciousness of state) $\mathrm{X}$, misalnya.

Dalam rangka menjawab pertanyaan tentang hubungan rasamerasa di atas sekaligus menyangkal empirisisme, Merleau-Ponty menjelaskan dengan menarik soal proses berlangsungnya pengalaman rasa. Ia mengilustrasikannya seperti saat orang tertidur. Tidur terjadi dan berlangsung melalui serangkaian sikap yang setelah sekian waktu dilakukan tiba-tiba saja membuat orang terlelap. Orang menutup mata, menarik serta menghembuskan napas dengan ritme yang stabil. "Respirasi dengan ritme tertentu itu, yang beberapa saat lalu saya pertahankan dengan sukarela, sekarang menjadi pengada saya." 28 Tidur akhirnya menjadi sebuah situasi. Ketika membandingkannya dengan soal sakramen (dalam Kristianitas) yang bukan sekadar menyimbolkan berkat, Merleau-Ponty menjelaskan bahwa hal itu menghadirkan Tuhan secara nyata bagi si penerima sakramen. Melawan pandangan empirisis tentang makna sensasi, MerleauPonty menyatakan bahwa apa yang dapat dirasakan (sensible) bukan hanya kualitas dari penggerak, tetapi "cara mengada tertentu di dalam dunia yang disugestikan pada kita dari suatu titik dalam ruang, dan yang ditangkap, dan yang diwujudkan dalam tindakan dengan tubuh kita." ${ }^{29}$ Dari pernyataan Merleau-Ponty ini tampak bahwa makna sensasi itu terberi sebagai cara mengada manusia di dalam dunia.

Masih dalam rangka menelaah persoalan rasa-merasa, MerleauPonty juga mengajukan argumen yang melawan intelektualisme. Pada intelektualisme, sensasi atau persepsi merupakan sensasi atau persepsi atas suatu objek. Maka, terdapat hubungan antara subjek dengan objek. 
Berdasarkan hubungan itu, aku memiliki rasio dan kesadaran yang mampu mendeterminasi sensasi dan persepsi atas objek. Pengalamanku menjadi pengalaman yang objektif, atau yang dalam bahasa Merleau-Ponty disebut sebagai "pengalaman yang tak terkomunikasikan." ${ }^{30}$ Hakikat objek-objek pun sangat bergantung pada keputusan yang dibuat subjek. Padahal, menurutnya, objek dapat ditentukan hanya melalui terbukanya berbagai pengalaman yang mungkin. Intelektualisme memperlakukan organ-organ perasa (sense organs) sebagai instrumen bagi persepsi subjek. MerleauPonty berpendapat bahwa orang tidak bisa memastikan bahwa organ instrumental yang ada pada tubuhnya senantiasa mempunyai daya kognitif, lantaran persepsi sesungguhnya bersifat ambigu.

Di samping mengobjektivikasi sensasi dan tubuh, intelektualisme juga bertendensi mereduksinya menjadi pengetahuan akan kualitas tertentu (quale). Kualitas tersebut memiliki kategori yang universal dan tetap sehingga dipahami secara sama pula meski dalam ruang dan waktu yang berbeda. Merleau-Ponty justru memandang bahwa kualitas yang demikian memancarkan suatu cara bereksistensi (mode of existence). Maka, hubungan rasa-merasa sesungguhnya dapat menjadi hubungan yang simpatik, yakni ketika rasa tidak pertama-tama diperlakukan sebagai objek. Terkait kritik terhadap intelektualisme ini, ada penjelasan menarik dari Merleau-Ponty. Ia menggambarkan hubungan antara sensor rasa dan yang dirasakan seperti saat orang merenungi birunya langit. Dalam kontemplasiku atas birunya langit, aku tidak berhadapan dan menganalisisnya seakan-akan aku ini "a-kosmis", terlepas dari realitas. Aku tidak memilikinya secara ekskulif di dalam pikiran, atau menerapkan berbagai rumusan ide tentang apa itu biru terhadap langit. Dengan puitis Merlau-Ponty menyatakan, "Langit biru itu memikiran dirinya sendirinya padaku. Aku adalah langit itu sendiri." 31 Persepsi bukanlah hasil refleksi yang ketat dan terukur dari pikiran subjek.

Tendensi empirisisme dan intelektualisme dalam memaknai pengalaman rasa menggiring pada sebuah dilema. Merleau-Ponty menyebutnya sebagai dilema karena keduanya itu membuat orang harus memilih di antara dua pilihan, tidak lebih dan tidak kurang, yakni: atau persepsi itu termasuk eksistensi berkesadaran atau eksistensi yang nir-kesadaran. Ia mencari jalan keluar dari dilema macam ini. Argumentasi pertamanya adalah bahwa "setiap persepsi berlangsung dalam sebuah atmofser generalitas dan ditampilkan kepada kita secara anonim." ${ }^{32}$ 
Adapun yang dimaksud dengan atmofser generalitas adalah ketika orang mempersepsikan sesuatu, terdapat konteks situasi yang menyertai persepsinya. Ada suasana yang seolah-olah membimbingnya merasakan bahwa langit yang dipandanginya penuh gradasi warna, dan pada satu momen ia mengekspresikannya: langit itu berwarna biru. Dalam mempersepsikan langit biru itu, menurut Merleau-Ponty, terdapat sensitivitas terhadap warna. Konteks situasi sendiri tercipta dari berbagai tindakan personal seseorang, antara lain berupa pilihan hidupnya. Bagi Merleau-Ponty jelas bahwa pengalaman perseptual terjadi ketika orang dipersepsikan oleh sesuatu dan bukannya ia yang mempersepsikan. ${ }^{33}$ Orang mengalami rasa tanpa mesti memilah serta menilainya menurut kategori-kategori dan tanpa mesti menyatakannya sebagai objek. Tentang anonimitas, Merleau-Ponty menyebutkan bahwa itu hanya terjadi karena sensasi orang tidaklah lengkap. Apa yang dilihat, didengar, dan disentuh hanyalah bagian tertentu saja dari sebuah objek. Selalu ada bagian yang tidak dilihat, didengar, dan disentuh. Ada porsi yang melampaui dari apa yang kulihat, kudengar, dan kusentuh pada momen ini. ${ }^{34}$

Merleau-Ponty menyimpulkan perihal atmofser generalitas dan anonimitas di atas dengan gagasan tentang "lapangan rasa". Setiap sensasi berada pada sebuah lapangan tertentu. ${ }^{35}$ Lapangan inilah yang membuat orang memiliki akses ke sekaligus terbuka pada cara mengada. MerleauPonty mencontohkannya dalam hal penglihatan atau visi. Dengan lapangan rasa yang demikian, visi merupakan sesuatu yang pra-personal. Di samping itu, visi juga senantiasa terbatas. "Visi adalah sebuah pemikiran yang disubordinasikan pada lapangan tertentu dan itulah yang disebut dengan sebuah rasa." ${ }^{36}$

\section{Tentang Kesatuan Rasa, Sikap Analitis, dan Hakikat Tubuh}

Mengikuti Marshall, tesis lain yang diajukan oleh Merleau-Ponty adalah bahwa terdapat kesatuan rasa ketika orang mengalami pengalaman rasa. ${ }^{37}$ Tesis ini sebenarnya merupakan pendalaman dari tesis sebelumnya tentang makna pengalaman rasa. Dengan tesis ini, Merleau-Ponty kembali mengkritik tendensi empirisisme dan intelektualisme. Kini ia memandang keduanya sebagai sebentuk refleksi saintifis terhadap persepsi. Ia menyebutnya sebagai "sikap analitis" (analytic attitude). Dalam rangka membuktikan bahwa rasa memiliki kesatuan dan saling terkait satu sama 
lain, Merleau-Ponty membahas kembali hakikat tubuh. Konsep "skema bertubuh" muncul di bagian ini. Argumentasinya lebih bersifat deskriptif, sebab ia lebih banyak menggambarkan contoh-contoh untuk mendasarkan tesis tersebut. Dengan adanya makna pengalaman rasa, sensasi, organ perasa, dan hubungan rasa-merasa bukanlah hasil objektivikasi. Hal ini dipertegas oleh Merleau-Ponty dalam tesis kesatuan rasa dan hakikat tubuh. Ia menyatakan bahwa makna yang ada bukanlah koleksi sensasi bertubuh melainkan bahwa tubuh itu memakai bagian-bagiannya sendiri sebagai sistem simbol-simbol bagi dunia. ${ }^{38}$

Merleau-Ponty melanjutkan kritiknya terhadap tendensi intelektualisme dalam memahami rasa. Ia berangkat dari gagasan sebelumnya tentang lapangan sensasi. Kalau sensasi mempunyai lapangan tertentu, bukankah berarti ada berbagai jenis lapangan yang bisa dipersepsikan atau dirasakan secara berbeda satu sama lain? Ia menyatakan bahwa pembedaan antara berbagai rasa menemukan justifikasinya bersamaan dengan pembedaan antara rasa dan tindakan menalar (intellection). ${ }^{39}$ Itulah pandangan yang dianut intelektualisme, yakni menganggap bahwa sensasi dan rasa hanya muncul dari pengetahuan yang menganalisisnya. Bagaimana dengan empirisisme? Menurut Merleau-Ponty, empirisisme tidak mampu menyanggah pandangan deduktif intelektualisme tersebut. Empirisisme justru mengembalikan sensasi dan rasa pada kausalitas. Dalam hal penglihatan, misalnya, empirisisme menganggap bahwa yang memungkinkan orang melihat sesuatu adalah karena adanya ruang (space) fisik. Proses rasa-merasa pun berlangsung sebagai berikut. Orang melihat dalam sebuah ruang, lalu penglihatannya itu ditransmisikan ke indera-indera perasa yang lain. Maka, empirisisme meyakini adanya spasialitas rasa serta adanya metode induktif untuk membangun persepsi akan rasa tersebut. ${ }^{40}$

Merleau-Ponty menanggapi problem di atas dengan menggali duduk perkara yang sesungguhnya. Di balik tendensi empirisisme dan intelektualisme itu terdapat model refleksi yang mendasari. Ia berpendapat bahwa baik empirisisme maupun intelektualisme bersandar pada refleksi yang mentematisasi objek dan kesadaran. Dalam bahasa kantian, refleksi yang demikian "mengantarkan pada konsep." ${ }^{41}$ Akibat refleksi ini, objek merupakan sesuatu yang bisa dianalisis. Objek menjadi 'apanya' (what is) yang berlaku secara umum, sedangkan kesadaran 'adalah' (is) eksistensi yang berkesadaran. ${ }^{42}$ Untuk itu Merleau-Ponty menawarkan model refleksi 
baru yang dinamakannya "refleksi radikal". Ini adalah refleksi sebelum aku membentuk dan memformulasikan ide tentang subjek dan objek. ${ }^{43}$ Merleau-Ponty menggambarkan refleksi radikal ini sebagai berikut. Dengan refleksi ini, pengalaman atas dunia bukanlah seperti sistem hubungan yang menentukan tiap peristiwa, melainkan sebagai sintesis terbuka yang tiada habisnya. Dengan refleksi ini, seseorang mengalami dunia bukan menurut subjektivitas yang mutlak, melainkan subjektivitas yang terus-menerus diperbaharui dalam arus waktu. ${ }^{44}$

Argumentasi tentang refleksi radikal dipakai Merleau-Ponty untuk menanggapi klaim intelektualisme dan empirisisme terhadap kesatuan rasa. Intelektualisme memandang kesatuan rasa secara a priori. Pandangan ini merujuk pada deduksi transendental Kant, yakni ide bahwa terdapat suatu ruang dan waktu yang mendasarkan pengalaman manusia. Dengan deduksi transendental, orang memperoleh objektivitas pengalaman. Refleksi radikal akan mengurung (bracketing) pandangan a priori ini guna mencapai pengalaman yang asali. Menurut Merleau-Ponty, konsepsi fenomenologis ini memberi pengertian yang baru atas konsep a priori. Ia menunjukkan bahwa Kant sebenarnya sudah membahas soal kebaruan ini, yakni ketika memperlihatkan bahwa yang a priori tak terpahami di luar pengalaman. Faktisitas manusia, hidupnya yang begini adanya merupakan horizon pemahaman itu. Kalau begitu, tidak berlaku lagi pembedaan antara elemen pengetahuan yang a priori dan yang a posteriori.$^{45}$ Dengan terhapusnya distingsi tersebut, spasialitas pengalaman pun menjadi pengalaman yang konkret. Pengalaman menjadi pengalaman yang dihidupi dan "kesatuan rasa dapat ditemukan hanya dari kesalingan di antara dunia rasa." ${ }^{46}$ Namun, bukankah dengan begitu berarti ada pemisahan rasa sehingga orang kembali masuk ke dalam empirisisme?

Merleau-Ponty menjawab pertanyaan reflektif ini secara negatif. Baginya, tidak ada pemisahan rasa. Alasannya ialah, tiap organ perasa sesungguhnya mengeksplorasi objek yang ada dengan sensitivitasnya masing-masing. Eksplorasi itu akhirnya akan membentuk sejenis sintesis tertentu. "Penglihatan kita tidak akan pernah berkomunikasi secara langsung dengan sentuhan kita apabila indera sentuhan tidak teroganisir untuk memungkinkan ko-eksistensi." ${ }^{\prime 47}$ Pada persepsi visual, MerleauPonty menggambarkan, mesti ada kuasi-lapangan-sentuhan (quasi-tactile field). Pembedaan atau pemisahan rasa hanya dimungkinkan karena setiap 
rasa tidak dapat bertransposisi. Baginya, hal ini dapat dihindari dengan cara kembali pada tubuh sebagai subjek persepsi.

Merleau-Ponty menyelidiki lebih jauh problem klaim kesatuan rasa. Kali ini ia meneliti perihal sikap analitis yang diterapkan oleh intelektualisme dan empirisisme. Ia menuangkan pendapatnya tentang empirisisme dalam sebuah paragraf yang cukup panjang. Ada dua contoh yang paling tegas menggambarkan duduk perkara sikap analitis versi empirisisme, yakni contoh tentang visi terhadap kertas dan pengaruh obat mescalin. Apa yang dilawan oleh Merleau-Ponty adalah pandangan bahwa rasa sama dengan kualitas yang terasa (sensible quality); bahwa terdapat quale yang dipersepsikan melalui serangkaian observasi. Ia mencontohkan pengalaman dirinya sendiri. Ia berkisah,

"Aku sedang duduk di ruanganku, dan aku memandangi helai-helai kertas putih yang tergeletak di meja, beberapa di antaranya terkena sinar dari jendela, yang lainnya berada dalam bayang-bayang. Apabila aku tidak menganalisis persepsiku, tapi menerima penampilan yang ada sebagai keseluruhan, aku pasti akan berkata bahwa semua helai kertas itu terlihat setara berwarna putih. Sebaliknya, aku akan melihat warna helaihelai kertas tersebut tidak sama manakala aku bersikap analitis."48

Merleau-Ponty mencontohkan sikap analitis tersebut seperti melihat helai kertas melalui lubang kotak korek api. Problem sikap analitis versi empirisisme adalah merekayasa persepsi sedemikian rupa sehingga persepsi diperlakukan secara instrumentalis. Sikap ini didorong oleh projek saintifis terhadap fenomena. Maka, dunia pun diatomisasikan menjadi kualitaskualitas yang terasa. ${ }^{49}$

Masih ada beberapa contoh lain yang disajikan Merleau-Ponty dalam rangka menjelaskan duduk perkara di atas, seperti ambiguitas visi ketika melihat gerakan stroboskopik, ketika intensitas suara atau bunyi mempengaruhi ritme suatu gerakan. Persepsi natural saat melihat gerakan stroboskopik, menurut Merleau-Ponty, merupakan sanggahan terhadap hipotesis ketetapan yang meyakini bahwa setiap rangsangan hanya memberi satu, dan hanya satu sensasi. Contoh yang tak kalah menarik adalah tentang efek obat mescalin. Ringkasnya, obat ini menghasilkan pengalaman tak lazim yang disebut sebagai pengalaman synaesthetis. Orang yang berada di bawah pengaruh obat ini akan mengalami sensasi secara terbalik: sensasi suara sebagai sensasi warna. Merujuk pada studi dari Mayer-Gross dan Stein, Merleau-Ponty memperlihatkan bahwa suara gonggongan seekor anjing 
ternyata merangsang warna tertentu lalu bergema lagi pada kaki kanan seseorang. ${ }^{50}$ Bagi Merleau-Ponty, kasus efek mescalin ini membuktikan betapa cara pandang objektif terhadap rasa tidaklah memadai. Rasa bukanlah kualitas dan sensasi atasnya bukanlah proses yang berlangsung secara terbatas pada bagian otak tertentu. ${ }^{51}$ Pengalaman efek mescalin memperlihatkan adanya fenomena seorang yang melihat bunyi dan mendengar warna. Menurutnya, hal ini akan tetap tidak masuk akal apabila visi diartikan sebagai quale visual, dan bunyi sebagai quale akustik. Bagi Merleau-Ponty, penyebabnya adalah pengetahuan saintifis yang menggeser pusat gravitas pengalaman, yakni kebertubuhan. Akibatnya, orang tidak melihat, mendengar, dan merasakan apa yang tubuhnya sendiri hidupi.

Intelektualisme juga menganut sikap analitis. Dalam pandangan intelektualisme, rasa dimengerti seperti data kualitatif sehingga setiap rasa pada dasarnya merupakan kualitas yang tak terbandingkan (incomparable) satu sama lain. Duduk perkaranya di sini, menurut Merleau-Ponty, ialah bahwa setiap rasa menjalin suatu interkomunikasi. Rasa tidak terpisahpisah, seolah-olah memiliki dunianya masing-masing. Mereka semua berkomunikasi melalui inti makna mereka. ${ }^{52}$ Ketika menyentuh sebuah benda, misalnya, orang dapat merasakan bentuknya sehingga ia tahu bahwa benda yang ini berat, ringan, panas, atau dingin. Ketika mendengar suara aspal panas dalam proses perataan jalan, orang merasakan sesuatu yang kasar dari bunyi gesekan alat pekerjanya. Namun, apakah interkomunikasi rasa ini membuat pengalaman indera perasa menjadi satu-kesatuan? Apakah persepsinya itu memasukkan segala pengalaman sensorisnya ke dalam satu dunia, seperti objek atau fenomena yang disatukan dalam penjelasan saintifis ${ }^{53}$ Merleau-Ponty menjawab, tidak. Penyatuan rasa terjadi seperti visi melalui dua mata atau binokular (binocular vision).

Apakah berarti kesatuan rasa terbentuk dari gabungan dua retina yang melihat satu objek? Apakah berarti ada divergensi dan konvergensi mata? Bagi Merleau-Ponty, visi binokular bukan hasil dari sudut pandang orang ketiga yang menciptakan satu jenis gambar objek melalui penggabungan (fusion) dua gambar dari masing-masing satu penglihatan (monocular). ${ }^{54}$ Sintensis visi dalam visi binokular bukanlah hasil pikiran subjek, melainkan berkat tubuh kita yang memang sudah memiliki lapangan visi tersebut. Merleau-Ponty mendasarkan pendapatnya tentang sintesis perseptual tersebut pada konsep "skema bertubuh" (bodily schema). Menurutnya, sintesis tersebut terbentuk dari intensionalitas tubuh yang mempersepsi 
objek. Dengan skema bertubuh, sintesis perseptual orang selalu terarah dan bahkan dipengaruhi oleh objek itu sendiri. ${ }^{55}$ Oleh sebab itu, seseorang senantiasa dibentuk oleh objek yang dibicarakan atau dirasakannya. Dengan adanya skema bertubuh, tubuh menjadi terbuka akan serangkaian pengalaman. Merleau-Ponty menyatakan bahwa objek merupakan "terminasi transenden dari serangkaian pengalaman yang terbuka." 56 Intelektualisme dengan sikap analitisnya gagal memahami hal ini.

Berdasarkan tinjauannya terhadap sikap analitis dan skema bertubuh, Merleau-Ponty berpendapat bahwa kesatuan rasa tidak bisa dipahami sebagai suatu penggolongan (subsumption) berdasarkan kesadaran. ${ }^{57}$ Kesatuan rasa bukan hasil dari proses memasukkan berbagai rasa ke dalam satu jenis kategori, melainkan integrasi sensoris yang tiada akhirnya. Ia mempertegas gagasannya bahwa berbagai rasa berinterkomunikasi dengan ilustrasi kegiatan menonton film. Saat menonton sebuah film berbahasa Inggris yang dilengkapi dengan teks (subtitle) berbahasa Perancis, orang merasakan kaitan tertentu antara teks Prancis dengan gerak tubuh para aktor dan aktris yang bertutur dalam bahasa Inggris. Merleau-Ponty menyatakan bahwa gerak tubuh dan kata-kata tidak digolongkan di bawah kategori tertentu. Kata-kata mengisi gerak dan gerak mengisi tubuh dan mereka berinterkomunikasi melalui tubuh..$^{58}$ Artinya, yang memungkinkan rasa bertransposisi dan membentuk sintesis adalah tubuh. Di sini, MerleauPonty kembali mengungkapkan pentingnya konsep skema bertubuh. Dengan skema bertubuh, bukan hanya kesatuan tubuh yang digambarkan secara baru, tapi juga kesatuan rasa dan objek. ${ }^{59}$

Hakikat tubuh yang berkesatuan juga bisa dilihat dari pengalaman rasa dalam ranah kultur. Merleau-Ponty menggambarkan hal ini sebagai pemaknaan objek-objek kultural oleh tubuh. Ia mencontohkan ketika sebuah kata diperlihatkan secara sekilas pada seseorang sehingga orang itu membacanya secara sekilas pula. Pada momen yang sekejap itu, kata 'hangat' akan memberi kesan pengalaman kehangatan pada orang tersebut. Juru masak yang sedang berkompetisi pun mempresentasikan masakannya dengan nama dan bentuk yang menarik, sedemikian rupa sehingga membangkitkan selera makan. Dengan begitu, Merleau-Ponty menegaskan bahwa tubuh tidak seperti objek di antara objek lainnya, tetapi objek yang sensitif terhadap yang lainnya. ${ }^{60}$ Dalam ungkapan MerleauPonty, tubuh menggemakan suara, memantulkan warna, dan memaknai kata-kata sebagaimana kata-kata itu diterima oleh tubuh. 


\section{Ambiguitas Pengalaman Rasa}

Merleau-Ponty berargumentasi cukup panjang perihal pengalaman rasa dan hakikat kebertubuhan. Pengalaman rasa berkenaan dengan segala sesuatu yang sudah selalu dihidupi seseorang bersama dan melalui tubuhnya. Pengalaman rasa menyangkut baik objek-objek natural maupun kultural. Merleau-Ponty juga telah menerangkan berbagai contoh serta argumentasi terkait semua itu. Kendati demikian, ia mempertimbangkan, apakah semuanya itu bakal tetap tinggal sebagai deskripsi penampakan belaka? Akankah gagasan tentang pengalaman rasa ini didiskreditkan oleh pandangan populer? Sebab, "sebagaimana dipahami secara populer, tubuh milik seseorang merupakan sebuah objek yang dibentuk sekaligus yang membentuk dalam hubungannya dengan objek-objek yang lain." ${ }^{61}$ Dengan pertimbangan ini, Merleau-Ponty ingin menunjukkan betapa kuat tendensi empirisisme dan intelektualisme dalam memahami pengalaman rasa serta hakikat kebertubuhan. Ada dilema yang terus-menerus menghantui. Ia meyakini hal ini. Baginya, berlaku kecenderungan umum, yakni entah diri manusia bersemayam ke dalam instrumen material bernama 'rasa' atau 'tubuh', atau dirinya merupakan hasil refleksi seorang subjek yang berkesadaran. ${ }^{62}$ Kecenderungan yang disebut pertama adalah tendensi empirisisme, sedangkan yang kedua adalah tendensi intelektualisme. Yang pertama meniadakan sama sekali subjek yang mempersepsi. Yang ada hanya "sesuatu untuk melihat" namun "tiada seorang pun yang melihat." 63 Yang kedua memusatkan subjek yang berkesadaran, yakni subjek yang mengetahui bahwa dirinya menyadari objek-objek.

Merleau-Ponty mengemukakan tanggapannya atas dilema itu dalam sebuah paragraf panjang. Ia kembali membahas perihal sintesis perseptual. Baginya, mempersepsi tidak sama dengan memikirkan objek atau memikirkan pikiran tentang objek. Seperti yang telah ditunjukkan dengan skema bertubuh, tubuh sudah memahami dunia, termasuk segala motif dan sarana untuk membuat sintesis tentangnya. ${ }^{64}$ Maka, yang ada adalah sebuah pengalaman yang hidup atas kesatuan rasa. Akan tetapi, apa yang menghidupkan pengalaman yang hidup itu sendiri, kalau bukan tubuh materialku ataupun kesadaran akan pengalaman tersebut? Bukankah rasa dibentuk seperti data murni atau seperti sesuatu yang diterima secara pasif? Dalam menjawab pertanyaan ini, Merleau-Ponty berpendapat bahwa sintesis perseptual bersifat temporal dan subjektivitas sendiri merupakan 
temporalitas. ${ }^{65}$ Artinya, segenap rasa dan persepsi terkait dengan waktu yang terus bergulir silih berganti. Maka itu, tubuh memiliki kepadatan dan historisitasnya sendiri. ${ }^{66}$ Menurutnya, pengalaman rasa berlangsung baik secara prospektif maupun retrospektif. Maksudnya, pengalaman rasa terfokus pada objek yang ada di hadapannya sekaligus muncul dari berbagai dorongan yang mendahuluinya. Tampak bahwa waktu tidak bersifat tertutup, melainkan terbuka. Sintesis perseptual didasarkan pada keterbukaan waktu ini. ${ }^{67}$ Waktu dibentuk oleh subjektivitas sehingga seseorang bisa menyatakan bahwa pengalaman $\mathrm{X}$ adalah pengalaman milik dirinya, namun waktu jugalah yang membentuk diri orang itu. Ambiguitas pengalaman rasa merupakan konsekuensi temporalitas manusia yang senantiasa terbagi-bagi.

Pada bagian terakhir bab ini, Merleau-Ponty mengajukan semacam pembelaan atas gagasannya tentang temporalitas. Seperti yang telah diuraikan di atas, pengalaman rasa itu berwaktu. Kalau kembali pada duduk perkara di balik sikap analitis intelektualisme dan empirisisme, aspek temporalitas ini mengukuhkan model refleksi radikal sebagai solusi atas problem dua sikap analitis tersebut. Bagi para intelektualis, refleksi berarti "penjarakan atau pengobjektivikasian sensasi dan mengkonfrontasinya dengan seorang subjek." ${ }^{68}$ Adapun bagi kaum empirisis, refleksi tak lain ialah observasi atas 'apa' yang kulihat, kudengar, atau kurasakan. Dalam melawan itu semua, tugas refleksi radikal, menurut Merleau-Ponty, adalah "mengangkat pengalaman yang tak reflektif atas dunia, menguntukkan sikap verifikatif dan tindakan reflektif bagi pengalaman itu, dan menampilkan refleksi sebagai salah satu kemungkinan caraku mengada." ${ }^{9}$

\section{Simpulan}

Ada beberapa catatan yang bisa disampaikan tentang isi bagian buku Phenomenology of Perception ini. Teks ini menyajikan sebuah deskripsi yang sangat padat dengan argumentasi-argumentasi kompleks. Deskripsi tersebut merupakan gambaran fenomenologis tentang pengalaman rasa. Dari topiktopik yang dibahas di atas, saya berpendapat bahwa pengalaman rasa yang dikemukakan Merleau-Ponty merupakan pengalaman yang dihidupipengalaman rasa sebagai pengalaman yang dihidupi. Dalam teks ini bisa dilihat setidaknya dua ide pokok Merleau-Ponty, yakni pengalaman rasa bersama dan melalui tubuh serta penghayatan tubuh bersama dan melalui 
dunia. Seseorang membicarakan dunia, tapi ia sendiri merupakan bagian dari dunia. Tubuhlah yang memungkinkan berlangsungnya ambiguitas semacam itu. Kedua gagasan ini tampak pada pemaknaan pengalaman rasa dalam kaitannya dengan kesatuan rasa dan kritik terhadap sikap analitis.

Pada simpulan ini bisa ditengok kembali kisah juru masak yang mengikuti kompetisi masak di atas. Menurut saya, kisah juru masak ini sejalan dengan dekripsi Merleau-Ponty tentang pengalaman rasa. Kendati begitu, kata 'rasa' tidak harus disamaartikan sebagai rasa atau aroma masakan belaka. Pengalaman rasa melibatkan keseluruhan eksistensi juru masak beserta juri yang menilai hasil masakannya. Maksudnya, apa yang mereka rasakan tidak hanya merujuk pada kinerja indera-indera perasa, tetapi juga segenap ekspresi yang timbul bersama dan melalui tubuhnya. Ekspresi menyangkut makna yang terberi bagi setiap pihak yang mengalaminya. Hal ini dimungkinkan bukan karena terdapat kausalitas unit-unit rasa hasil pengobservasian seperti yang diyakini kaum empirisis, bukan pula berkat penilaian kesadaran subjek atas suatu objek seperti yang diusung oleh intelektualisme.

Yang menangkap makna dalam pengalaman rasa tak lain adalah tubuh sendiri. Tubuh sudah mengenali sensasi dan persepsi yang diterima seseorang. Untuk mengungkapkan dalam bahasa heideggerian, tubuh adalah "rumah pengada." Skema bertubuh memperlihatkan bahwa tubuh adalah semacam tujuan akhir bagi pengalaman. Artinya, rasa dialami bersama dan melalui tubuh dalam mengada di dunia. Di samping itu, temporalitas tubuh mengungkapkan aspek kemewaktuan tubuh sehingga tubuh selalu saja lolos dari berbagai kebakuan dan objektivikasi. Lantas bagaimana cara menghayati hakikat kebertubuhan? Sebagai pengikut setia fenonemologi, Merleau-Ponty akan menjawab: dengan kembali ke pengalaman yang pra-personal.

Merleau-Ponty menyatakan bahwa pengalaman yang pra-personal, pra-objektif, serta pra-sadar merupakan persepsi yang utama. ${ }^{70}$ Yang bisa menghantar orang masuk ke dalam pengalaman seperti itu adalah refleksi radikal. Akan tetapi, hal ini memicu pertanyaan kritis: apa yang mendorong refleksi radikal tersebut? Di satu sisi, Merleau-Ponty menggarisbawahi tugas penting refleksi radikal, yaitu secara paradoksal menyentuh dimensidimensi yang nonreflektif alias yang belum dikonsepsikan secara empirisis ataupun intelektualis. Di sisi lain, sifat rasional yang ditampilkan oleh 
empirisisme dan intelektualisme mau tidak mau mesti ada kalau mau melakukan refleksi radikal. Dengan kata lain, refleksi radikal sebenarnya mengandaikan pula refleksi yang rasionalis. ${ }^{71}$ Kendati demikian, refleksi radikal berbeda dari refleksi rasionalis. Refleksi radikal mampu menampilkan sekian kemungkinan cara mengada berkat berkelindannya persepsi dan dunia, sedangkan refleksi yang rasionalis mengkerangkakan baik persepsi maupun dunia tersebut menurut kualitas-kualitas tertentu. Seperti yang Merleau-Ponty sendiri sudah antisipasi dalam teks ini, sikap kritis seperti halnya sikap analitis membawa orang masuk ke dalam pengalaman. Bagaimanapun juga, pengetahuan turut andil, baik dalam pengalaman rasa bersama dan melalui tubuh, maupun penghayatan tubuh bersama dan melalui dunia. Tentang peran pengetahuan ini MerleauPonty berkata, "mari kita dengan begitu katakan secara sementara waktu bahwa yang ada cuma bahan pengetahuan yang mungkin." 72 Refleksi radikal yang dianjurkan oleh Merleau-Ponty rupanya tak bisa lepas dari paradoks referensi diri.

Fenomena pengalaman rasa memperlihatkan interaksi yang intim antara tubuh dan realitas. Pendekatan saintifis yang memiliki asumsi dualisme subjek-objek pun tanggal sudah. Berseberangan dengan paradigma saintifis yang representasional, paradigma menurut pengalaman rasa ini adalah yang sinergis. Persepsi sendiri sesungguhnya merupakan sinergi. ${ }^{73}$ Dalam fenomena sinergi ini tubuh dengan segala realitas yang ada saling menjalin sehingga membentuk apa yang disebut Hall dengan "fenomena yang fundamental dari persepsi yang hidup."

\section{Bibliografi}

Marshall, George J. A Guide to Merleau-Ponty's Phenomenology of

Perception. Milwaukee: Marquette University Press, 2008.

Merleau-Ponty, Maurice. Phenomenology of Perception, trans. Colin Smith. London and New York: Routledge, 2002.

Hall, Lawrence. Merleau-Ponty's Philosophy. Bloomington, IN: Indiana University Press, 2008.

Tjaya, Thomas Hidya. "Merleau-Ponty. Intensionalitas Pengalaman dan

Persepsi” dalam Majalah Basis. Nomor 03-04. Tahun ke-63. 2014. 


\section{Endnotes:}

1 Mahasiswa Magister Ilmu Filsafat pada Sekolah Tinggi Filsafat Driyarkara, Jakarta. Email: sebastian_tanius@yahoo.com.

2 Maurice Merleau-Ponty, Phenomenology of Perception, trans. Colin Smith (London and New York: Routledge, 2002); selanjutnya disingkat PP diikuti dengan nomor halaman.

3 Thomas Hidya Tjaya, "Merleau-Ponty. Intensionalitas Pengalaman dan Persepsi," Majalah Basis, Nomor 03-04, Tahun ke-63 (2014) 43.

4 PP, 167.

5 George J. Marshall, A Guide to Merleau-Ponty's Phenomenology of Perception (Milwaukee: Marquette University Press, 2008), 125.

$6 \quad P P, 235$.

7 PP, 236.

$8 \quad$ Ibid.

$9 \quad P P, 239$.

10 Ibid.

11 Tjaya, art. cit., 43.

$12 P P, 241$.

$13 P P, 242$.

$14 P P, 239$.

$15 P P, 240$.

$16 P P, 242$.

$17 P P, 240$.

18 PP, 241.

19 Ibid.

20 Ibid.

21 PP, 242.

22 Marshall, op. cit., 130.

23 PP, 242.

$24 P P, 243$.

25 PP, 244.

26 Ibid.

27 PP, 245.

28 PP, 246.

29 Ibid.

30 Ibid.

31 PP, 249.

32 PP, 250.

33 Ibid.

34 PP, 251.

35 Ibid. 
36 PP, 251-252

37 Marshall, op. cit.,132.

38 PP, 275.

$39 P P, 252$.

$40 \quad P P, 253$.

41 PP, 254.

42 Ibid.

43 Ibid.

44 PP, 255.

45 PP, 256.

46 PP, 258.

47 PP, 259.

48 PP, 262.

49 PP, 264.

$50 \quad P P, 265$.

51 PP, 266.

52 PP, 267.

53 PP, 268.

54 PP, 270.

55 Ibid.

56 PP, 271.

57 Ibid.

58 PP, 273.

59 Ibid.

60 PP, 275.

61 Ibid.

62 PP, 276.

$63 P P, 275$.

$64 P P, 277$.

65 PP, 278.

66 Ibid.

67 Ibid.

68 PP, 280.

69 Ibid.

70 PP, 281

71 Menurut Merleau-Ponty, refleksi radikal adalah jenis refleksi baru. Refleksi ini berbeda dari refleksi yang mengobjektifikasi sensasi. Akibatnya, sensasi itu ditentukan oleh kesadaran akan pengalaman subjek yang menganalisis dan lantas mengolahnya menjadi pengetahuan. Merleau-Ponty memandang bahwa refleksi yang mengobjektifikasi ini adalah wujud dari refleksi berdasarkan intelektualisme dan empirisisme. Yang saya maksud dengan refleksi yang rasionalis di sini adalah refleksi yang intelektualis dan empiris ini. Corak refleksi jenis ini antara lain: (1) 
terdapat kesadaran subjektif akan pengalaman (apperception); (2) kesadaran tersebut membentuk "kesatuan sintetis"; (3) pengalaman dianalisis oleh kesadaran ini (Lih. PP, 280). Tampak bahwa refleksi yang rasionalis memahami pengalaman secara ideal. Pengalaman adalah pengalaman hasil analisis kesadaran dan pengetahuan. Dengan refleksi radikal, Merleau-Ponty mengajak kita untuk kembali ke pengalaman primordial, di mana dualitas antara subjek dan objek tidaklah berlaku. Dengan menjalankan refleksi radikal, "baik objek maupun subjek tidaklah dianggap sebagai benar" (PP, 281).

72 PP, 281; tekanan dari saya. Bagaimanapun juga Merleau-Ponty menekankan arti penting refleksi yang kembali ke pengalaman, atau yang secara paradoksal ia sebut sebagai "refleksi yang merujuk kepada sekian jumlah yang tidak reflektif dari pengalaman" (PP, 282).

73 Lawrence Hall, Merleau-Ponty's Philosophy (Bloomington, IN: Indiana University Press, 2008) 36. 